\title{
Effect of hepatitis B immunisation in newborn infants of mothers positive for hepatitis B surface antigen: systematic review and meta-analysis
}

\author{
Chuanfang Lee, Yan Gong, Jesper Brok, Elizabeth H Boxall, Christian Gluud
}

\begin{abstract}
Objective To evaluate the effects of hepatitis B vaccine and immunoglobulin in newborn infants of mothers positive for hepatitis B surface antigen.

Design Systematic review and meta-analysis of randomised clinical trials.

Data sources Electronic databases and hand searches.

Review methods Randomised clinical trials were assessed for methodological quality. Meta-analysis was undertaken on three outcomes: the relative risks of hepatitis B occurrence, antibody levels to hepatitis B surface antigen, and adverse events. Results 29 randomised clinical trials were identified, five of which were considered high quality. Only three trials reported inclusion of mothers negative for hepatitis B e antigen. Compared with placebo or no intervention, vaccination reduced the occurrence of hepatitis B (relative risk 0.28, 95\% confidence interval 0.20 to 0.40 ; four trials). No significant difference in hepatitis B occurrence was found between recombinant vaccine and plasma derived vaccine (1.00, 0.71 to 1.42; four trials) and between high dose versus low dose vaccine (plasma derived vaccine $0.97,0.55$ to 1.68 , three trials; recombinant vaccine $0.78,0.31$ to 1.94 , one trial). Compared with placebo or no intervention, hepatitis B immunoglobulin or the combination of plasma derived vaccine and hepatitis $\mathrm{B}$ immunoglobulin reduced hepatitis B occurrence (immunoglobulin $0.50,0.41$ to 0.60 , one trial; vaccine and immunoglobulin 0.08, 0.03 to 0.17 , three trials). Compared with vaccine alone, vaccine plus hepatitis $\mathrm{B}$ immunoglobulin reduced hepatitis $\mathrm{B}$ occurrence $(0.54,0.41$ to $0.73 ; 10$ trials). Hepatitis B vaccine and hepatitis B immunoglobulin seem safe, but few trials reported adverse events.

Conclusion Hepatitis B vaccine, hepatitis B immunoglobulin, and vaccine plus immunoglobulin prevent hepatitis $\mathrm{B}$ occurrence in newborn infants of mothers positive for hepatitis B surface antigen.
\end{abstract}

\section{Introduction}

Hepatitis B is a global communicable disease, associated with an estimated 350 million chronically infected patients. ${ }^{1}$ Mother to child transmission occurs often, either in utero or through exposure to blood or blood contaminated fluids at or around birth. Such perinatal transmission is believed to account for 35\% to $50 \%$ of hepatitis B carriers. ${ }^{2}$ The risk of perinatal transmission is associated with the hepatitis $\mathrm{B}$ e antigen status of the mother. If a mother is positive for both hepatitis B surface antigen and e anti- gen, $70 \%$ to $90 \%$ of her children become chronically infected. ${ }^{34}$ If a mother is positive for the surface antigen but negative for the e antigen, the risk of transmission is significantly lower. ${ }^{5-9}$

Two types of vaccines for hepatitis B have been licensed. One is derived from plasma (plasma derived vaccine) and the other is derived from yeast or mammalian cells (recombinant vaccine). ${ }^{10}$ Repeated injections over months are required to mount an effective antibody response with vaccination. Hepatitis B immunoglobulin has high levels of antibody to hepatitis B surface antigen. The immunoglobulin is immediately effective and seems protective for several months, after which it wanes. ${ }^{11}{ }^{12}$ In the present systematic review, we assessed the beneficial and harmful effects of hepatitis B vaccines and hepatitis B immunoglobulin in newborn infants of mothers positive for hepatitis B surface antigen.

\section{Methods}

We applied the Cochrane Collaboration methodology ${ }^{13}$ described in our predefined and peer reviewed protocol for this review. ${ }^{14}$ We included all trials that randomised newborn infants of mothers positive for hepatitis B surface antigen to hepatitis B vaccination and hepatitis $B$ immunoglobulin within the first month of life. We identified randomised trials from the registers of the Cochrane Neonatal Group, the Cochrane Hepato-Biliary Group, the Cochrane central register of controlled trials, Medline, PubMed, and Embase. The last search was carried out in February 2004. We scanned references lists and contacted manufacturers of hepatitis B vaccine to ask for unpublished randomised trials. We wrote to the authors of trials when data were not provided in the report. Our primary outcome measure was the occurrence of hepatitis $\mathrm{B}$, defined as a blood specimen positive for hepatitis B surface antigen, hepatitis B e antigen, or antibody to hepatitis $\mathrm{B}$ core antigen. ${ }^{15}$ The secondary outcome measures were antibody levels to hepatitis B surface antigen $<10 \mathrm{IU} / \mathrm{l}$ (considered insufficient to prevent hepatitis B virus infection $\left.{ }^{16}{ }^{17}\right)$ and adverse events.

We assessed the methodological quality of trials on the basis of their published reports, and information from the authors. We post hoc classified trials as high quality if they had at least two of the following components: adequate generation of allocation sequence, adequate allocation concealment, or adequate blinding. We did this because only one trial had high quality for all the components. We carried out meta-analyses using a fixed effect model and a random effects model in RevMan analyses 4.2. If the results of both analyses concurred, we reported the results of the fixed effect model only. 


\section{Research}

We presented binary outcomes as relative risks with 95\% confidence intervals. Data were analysed by the intention to treat principle, including all randomised participants. Heterogeneity was explored by $\chi^{2}$ test, with significance set at a $\mathrm{P}$ value $<0.10$. The extent of heterogeneity was measured by $\mathrm{I}^{2}{ }^{18}$ We carried out metaregression analysis using Stata if more than 10 trials were included on hepatitis B occurrence. Metaregression examined the intervention effect in relation to methodological quality of trials, dosage of hepatitis B immunoglobulin and vaccine, and time of injection. ${ }^{13}$ We carried out subgroup analyses according to methodological quality, hepatitis B e antigen status of the mother, and time of injection. We used the test for interaction to estimate the difference between two subgroups. ${ }^{19}$ For hepatitis B occurrence we included infants with incomplete or missing data in sensitivity analyses by imputing them into the following scenarios (the last four being intention to treat analyses): case analysis available, poor outcome assumed, good outcome assumed, extreme case favours experimental intervention, and extreme case favours control group. ${ }^{20}$ We used funnel plot and Stata to detect publication bias and other biases according to the methods of Begg and Egger. ${ }^{21}$

\section{Results}

Overall, 226 references were identified, 187 of which were excluded. The remaining 39 references, ${ }^{72-60}$ referring to 29 randomised clinical trials, were included. Three of the trials did not provide relevant data on our outcome measures (fig 1). ${ }^{29} 5860$

The immunisation schedules varied substantially. A number of trials had several intervention groups. Table 1 lists the relevant comparisons of the included trials. Eighteen trials included mothers positive for hepatitis B e antigen, three included mothers positive and negative for hepatitis $\mathrm{B}$ e antigen, and eight did not report on the mother's hepatitis B e antigen status. Ten trials reported exclusion of low birthweight infants (the limits for exclusion varied from $1600 \mathrm{~g}$ to $3000 \mathrm{~g}$ ). The remaining 19 trials did not report any exclusion criteria for birth weight. The average duration of follow-up was 19 months (range 6 to 60 months).

\section{Methodological quality of included trials}

Generation of the allocation sequence was adequately described in six trials. ${ }^{23} 2630314344$ Treatment allocation was adequately concealed in six trials. ${ }^{29-32} 4044$ Adequate methods of double blinding were reported in three trials. ${ }^{32}{ }^{32}{ }^{40}$ Five trials were classified by us as of high quality (table 2). ${ }^{30-32} 4044$ The numbers and reasons for drop outs and withdrawals were adequately described in six trials. 72429304452

\section{Hepatitis B vaccine versus placebo or no intervention}

Compared with placebo or no intervention, hepatitis B vaccination significantly decreased the risk of hepatitis $\mathrm{B}$ occurrence (relative risk $0.28,95 \%$ confidence interval 0.20 to 0.40 ; four trials) (fig 2). Heterogeneity was considerable $\left(\mathrm{P}=0.07, \mathrm{I}^{2}=54.2 \%\right)$. The results of sensitivity analyses for drop outs were consistent, indicating the robustness of the finding. Analyses of plasma derived vaccine and recombinant vaccine individually showed that both vaccines significantly decreased the risk of hepatitis B occurrence.

Subgroup analyses between high quality and low quality trials, the mother's hepatitis B e antigen status, or time of vaccination were not significantly different (tests for interaction, $\mathrm{P}=0.25, \mathrm{P}=0.07$, and $\mathrm{P}=0.11$, respectively).

Retrospective subgroup analyses according to vaccine schedules $(0,1$, and 6 months $v 0,1,2$, and 6 or 12 months) showed no significant difference (test for interaction, $\mathrm{P}=0.75$ ). No data on adverse events were reported.

\section{Recombinant vaccine versus plasma derived vaccine}

Recombinant vaccine and plasma derived vaccine showed no significant difference in hepatitis B occurrence $(1.00,0.70$ to 1.42 ; four trials) (fig 3). Heterogeneity was moderate $\left(\mathrm{I}^{2}=29.4 \%\right)$. Sensitivity analyses for drop outs confirmed the finding of no significant difference between the two vaccines. Subgroup analyses for methodological quality or mother's hepatitis B e antigen status showed no significant difference (tests for interaction, both $\mathrm{P}=0.21$.

Significantly fewer infants receiving recombinant vaccine compared with plasma derived vaccine had antibody levels to hepatitis B surface antigen <10 IU/1 $(0.51,0.36$ to 0.72 ; three trials).

\section{High dose versus low dose vaccine}

High dose vaccine and low dose vaccine showed no significant difference in hepatitis B occurrence (plasma derived vaccine $0.97,0.55$ to 1.68 , three trials; recombinant vaccine $0.78,0.31$ to 1.94 , one trial). Owing to too few trials, it was inappropriate to carry out sensitivity and subgroup analyses. No significant difference was found between high dose vaccine versus low dose vaccine on antibody levels to hepatitis B surface antigen $<10 \mathrm{IU} / 1$ (1.02, 0.82 to 1.27 ; two trials).

\section{Schedules and types of recombinant vaccine and plasma} derived vaccine

No significant differences were found in hepatitis B occurrences among different vaccination schedules, different recombinant vaccines, and different plasma derived vaccines (data not shown).

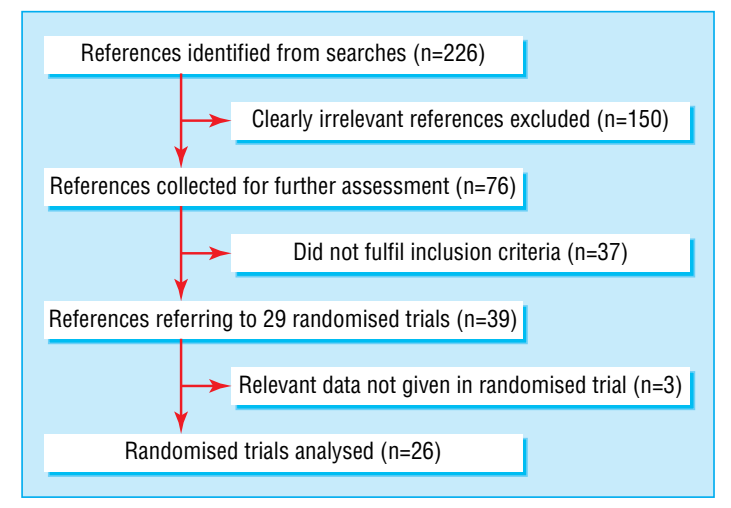

Fig 1 Flow diagram of trial selection 
Table 1 Interventions in experimental and control groups of included randomised clinical trials assessing effects of hepatitis $B$ vaccines and immunoglobulin for newborn infants of hepatitis B surface antigen positive mothers

\begin{tabular}{|c|c|}
\hline Trial & Experimental group \\
\hline $\begin{array}{l}\text { Assateerawatt } \\
1993^{23}\end{array}$ & $\begin{array}{l}\mathrm{A}^{*} \text { : Hepatitis } \mathrm{B} \text { immunoglobulin } 100 \mathrm{IU} \text { at } \\
\text { birth and recombinant vaccine } 20 \mu \mathrm{g} \text { at } \\
\text { birth and at } 1,2 \text {, and } 12 \text { months }\end{array}$ \\
\hline $\begin{array}{l}\text { Beasley } 1983^{7} \\
24\end{array}$ & $\begin{array}{l}\text { A: Hepatitis B immunoglobulin } 1.0 \mathrm{ml} \\
(180 \mathrm{IU}) \text { at birth and saline at } 3 \text { and } 6 \\
\text { months. C: Hepatitis B immunoglobulin } \\
0.5 \mathrm{ml}(90 \mathrm{IU}) \text { diluted in } 0.5 \mathrm{ml} \text { of } \\
\text { immune serum globulin at birth and at } 3 \\
\text { and } 6 \text { months }\end{array}$ \\
\hline Beasley $1983^{25}$ & $\begin{array}{l}\text { A: Hepatitis B immunoglobulin } 0.5 \mathrm{ml} \\
(145 \mathrm{IU}) \text { at birth and plasma derived } \\
\text { vaccine } 20 \mu \mathrm{g} \text { at } 4 \text { to } 7 \text { days. Followed by } \\
\text { boosters } 1 \text { and } 6 \text { months later }\end{array}$ \\
\hline Farmer $1987^{26}$ & $\begin{array}{l}\text { A: Plasma derived vaccine } 0.25 \mathrm{ml}(5 \\
\mu \mathrm{g})+ \text { +hepatitis B immunoglobulin } 0.25 \mathrm{ml} \\
(25 \mathrm{IU} / \mathrm{kg}) \text { at birth then plasma derived } \\
\text { vaccine+hepatitis B immunoglobulin } 0.25 \\
\mathrm{ml}(25 \mathrm{IU} / \mathrm{kg}) \text { at } 6 \text { weeks and plasma } \\
\text { derived vaccine at } 6 \text { months }\end{array}$ \\
\hline Garcia $1992^{27}$ & $\begin{array}{l}\text { A: } 10 \mu \mathrm{g} \text { recombinant vaccine- } 1 \text { at birth } \\
\text { and at } 1 \text { and } 2 \text { months }\end{array}$ \\
\hline $\begin{array}{c}\text { Grosheide } \\
1993^{29}\end{array}$ & $\begin{array}{l}\text { A: Hepatitis B immunoglobulin } 0.5 \mathrm{ml} / \mathrm{kg} \\
\text { body weight at birth and plasma derived } \\
\text { vaccine } 10 \mu \mathrm{g} \text { at } 2 \text { days and at } 1,2 \text {, and } \\
11 \text { months }\end{array}$ \\
\hline
\end{tabular}

: Recombinant vaccine $20 \mu 9$ at birth and at 1,2 , and 12 months

B: Saline at birth and 3 and 6 months

B. Hepatitis B immunoglobulin $0.5 \mathrm{ml}(145 \mathrm{IU})$ and plasma derived vaccine $20 \mu \mathrm{g}$ at 1 month. Followed by boosters 1 and 6 months later

B: Plasma derived vaccine 0.25 $\mathrm{ml}(5 \mu \mathrm{g})$ at birth and at 6 weeks and 6 months

B: $10 \mu \mathrm{g}$ recombinant vaccine- 2 at birth and at 1 and 2 months

B: Hepatitis B immunoglobulin $0.5 \mathrm{ml} / \mathrm{kg}$ body weight and plasma derived vaccine $10 \mu \mathrm{g}$ at $3,4,5$, and 11 months (with diphtheria, pertussis, tetanus, poliomyelitis concomitantly). Hepatitis B immunoglobulin 0.5 $\mathrm{ml} / \mathrm{kg}$ body weight at 3 months

\begin{tabular}{ll}
\hline Halliday $1992^{30}$ & $\begin{array}{l}\text { A: Recombinant vaccine } 20 \mu \mathrm{g} \text { at birth } \\
\text { and at } 1 \text { and } 6 \text { months. C: Hepatitis B } \\
\text { immunoglobulin } 260 \mathrm{IU} \text { at birth and } \\
\text { recombinant vaccine } 20 \mu \mathrm{g} \text { at birth and at }\end{array}$
\end{tabular}
B: Plasma derived vaccine 20 $\mu \mathrm{g}$ at birth and at 1 and 6 months. D: Hepatitis B immunoglobulin $260 \mathrm{IU}$ at birth and recombinant vaccine $10 \mu \mathrm{g}$ at birth and at 1 and 6 months

Hieu 2002 ${ }^{31} \quad$ A: Hepatitis B immunoglobulin $100 \mu \mathrm{g} \quad$ B: Hepatitis B immunoglobulin and $10 \mu \mathrm{g}$ recombinant vaccine-1 at birth $100 \mu \mathrm{g}$ and $10 \mu \mathrm{g}$ recombinant and Hepavax at 30 and 180 days

accine-2 at birth and Engerix-B at 30 and 180 days

Ip $1989^{32} 3354 \quad$ A: Plasma derived vaccine $3 \mu \mathrm{g}$ at birth $\quad$ B: Plasma derived vaccine $3 \mu \mathrm{g}$ and at 1,2, and 6 months. Also, hepatitis at birth and at 1,2, and 6 B immunoglobu hepatitis B immunoglobulin $100 \mathrm{IU}$ at monthly intervals during 6 months after birth. C: Plasma derived vaccine $3 \mu \mathrm{g}$ at birth and at 1,2 , and 6 months

\begin{tabular}{lll}
\hline Kang 1995 & $\begin{array}{l}\text { A: } 20 \mu \mathrm{g} \text { recombinant vaccine-1 at birth } \\
\text { and at } 1 \text { and } 6 \text { months }\end{array}$ & $\begin{array}{l}\text { B: } 20 \mu \mathrm{g} \text { recombinant vaccine-2 } \\
\text { at birth and at } 1 \text { and } 6 \text { months }\end{array}$
\end{tabular}
and at 1 and 6 months at birth and at 1 and 6 months

Khukhlovich A: Recombinant vaccine $1 \mathrm{ml}$ at birth and $\mathrm{B}$ : No vaccines

$1996^{35}$ at 1,2 , and 14 months

Kuru 1995 ${ }^{36} \quad$ A: Plasma derived vaccine $0.5 \mathrm{ml}(2.5 \quad$ B: Plasma derived vaccine $1 \mathrm{ml}$ $\mu \mathrm{g})$ and hepatitis B immunoglobulin $200 \quad(5 \mu \mathrm{g})$ and hepatitis B IU at birth and plasma derived vaccine at immunoglobulin $200 \mathrm{IU}$ at birth 1,2 , and 12 months. C: Recombinant and plasma derived vaccine at vaccine $0.5 \mathrm{ml}(10 \mu \mathrm{g})$, hepatitis $\mathrm{B}$ vaccine $0.5 \mathrm{ml}(10 \mu \mathrm{g})$, hepatits mmunoglobulin $200 \mathrm{IU}$ at birth and recombinant vaccine at 1,2 , and 12 months

Lee 1995 $37-39 \quad$ A: Hepatitis B immunoglobulin 145 IU $\quad$ B: Hepatitis B immunoglobulin and plasma derived vaccine $5 \mu \mathrm{g}$ at birth $145 \mathrm{IU}$ and plasma derived and $10 \mu \mathrm{g}$ recombinant vaccine-1 at $1,2, \quad$ vaccine $5 \mu \mathrm{g}$ at birth and and 12 months. C: Hepatitis B immunoglobulin $145 \mathrm{IU}$ and plasma derived vaccine $5 \mu \mathrm{g}$ at birth and $5 \mu \mathrm{g}$ recombinant vaccine-2 at 1,2 , and 12 months. E: Hepatitis B immunoglobulin $145 \mathrm{IU}$ at birth and plasma derived vaccine $5 \mu \mathrm{g}$ at birth and 1 month and 5 $\mu \mathrm{g}$ recombinant vaccine-2 at 2 and 12 months

and plasma derived vaccine $5 \mu \mathrm{g}$ at birth and plasma derived vaccine $5 \mu \mathrm{g}$ at 1,2 and 12 months. F: Hepatitis B immunoglobulin 145 IU at birth and plasma derived vaccine 5
Trial

Experimental group and at 1,2, and 6 months. C: Plasma birth and at 1,2, and 6 months derived vaccine $20 \mu \mathrm{g}$ at birth and at 1 2, and 6 months and hepatitis $B$ immunoglobulin at birth

Lo $1985^{28} 41 \quad$ A: Hepatitis B immunoglobulin $50 \mathrm{IU}$ at $\quad$ B: Plasma derived vaccine $5 \mu \mathrm{g}$ birth and plasma derived vaccine $5 \mu \mathrm{g}$ at at 2, 6, and 10 weeks

2,6 , and 10 weeks. C: Plasma derived vaccine $5 \mu \mathrm{g}$ at 2,6 , and 10 weeks and hepatitis B immunoglobulin $50 \mathrm{IU}$ at birth and at 1 month

Lolekha $2002^{42} \quad$ A: Recombinant vaccine $5 \mu \mathrm{g}$ at birth and B: Recombinant vaccine $5 \mu \mathrm{g}$ at 1 and 6 months

birth and at 1,2 , and 12

months

Oon $1986^{43} \quad$ A: Plasma derived vaccine $10 \mu \mathrm{g}$ at birth $\quad$ B: Plasma derived vaccine $5 \mu \mathrm{g}$ and at 1 and 2 months. C: Hepatitis B at birth and at 1 and 2 months. immunoglobulin $100 \mathrm{IU}$ and plasma $\quad$ D: Hepatitis B immunoglobulin derived vaccine $10 \mu \mathrm{g}$ at birth and plasma $100 \mathrm{IU}$ and plasma derived derived vaccine $10 \mu \mathrm{g}$ at 1 and 2 months vaccine $5 \mu \mathrm{g}$ at birth and plasma derived vaccine $5 \mu \mathrm{g}$ at 1 and 2 months

\begin{tabular}{lll} 
& 1 and 2 months \\
\hline Piazza 19854 & A: Plasma derived vaccine $5 \mu \mathrm{g}$ and & B: Plasma derived vaccine $5 \mu \mathrm{g}$
\end{tabular} hepatitis B immunoglobulin $50 \mathrm{IU}$ at birth and hepatitis B immunoglobulin and plasma derived vaccine at 1 and $2 \quad 50 \mathrm{IU}$ at birth and plasma months

\begin{tabular}{cl} 
& months \\
\hline Pongpipat & A: 200 IU hepatitis B immunoglobulin-1 \\
$1986^{45}$ & at birth and $5 \mu$ g plasma derived \\
& vaccine-1 at birth and at 1 and 6 months
\end{tabular}
derived vaccine at 2 months B: 100 IU hepatitis B immunoglobulin-2 at birth and vaccine- 1 at birth and at 1 and 6 months $10 \mu \mathrm{g}$ plasma derived vaccine-2 at birth and at 1 and 6 months

Pongpipat $\quad$ A: Plasma derived vaccine $5 \mu \mathrm{g}$ and $\quad$ B: Plasma derived vaccine $2 \mu \mathrm{g}$

$1988^{46}$ hepatitis B immunoglobulin $100 \mathrm{IU}$ at and hepatitis B immunoglobulin birth and plasma derived vaccine at $1,2, \quad 100 \mathrm{IU}$ at birth and plasma and 12 months

\begin{tabular}{cl}
\hline Pongpipat & A: Recombinant vaccine $5 \mu \mathrm{g}$ and \\
$1989^{47}$ & hepatitis B immunoglobulin $100 \mathrm{IU}$ at \\
& birth and recombinant vaccine at 1,2, \\
& and 12 months
\end{tabular}

derived vaccine at 1,2 , and 12 months

B: Plasma derived vaccine 10 $\mu \mathrm{g}$ and hepatitis B mmunoglobulin $100 \mathrm{IU}$ at birth and plasma derived vaccine at 1,2 , and 12 months

Poovorawan $\quad$ A: Recombinant vaccine $10 \mu \mathrm{g}$ and $\quad$ B: Recombinant vaccine $10 \mu \mathrm{g}$ $1997^{4849}$ hepatitis B immunoglobulin $100 \mathrm{IU}$ at at birth and at 1 and 6 months. birth and recombinant vaccine $10 \mu \mathrm{g}$ at 1 A booster was given at 60 and 6 months. A booster was given at 60 months months

Sehgal $1992^{50} \quad$ A: Hepatitis B immunoglobulin $0.5 \mathrm{ml}$ and $\quad B$ : Plasma derived vaccine 10 $51 \quad$ plasma derived vaccine $10 \mu \mathrm{g}$ at birth and $\mu \mathrm{g}$ at birth and at 4 and 8 plasma derived vaccine at 4 and 8 weeks weeks

Theppisai $\quad$ A: Hepatitis B immunoglobulin 200 IU $\quad$ B: Plasma derived vaccine 10

$1987^{52}$ and plasma derived vaccine $10 \mu \mathrm{g}$ at birth $\mu \mathrm{g}$ at birth and at 1 and 6 and plasma derived vaccine $10 \mu \mathrm{g}$ at 1 months and 6 months

Theppisai A: Hepatitis B immunoglobulin $200 \mathrm{IU}$ at $\quad$ B: Hepatitis B immunoglobulin

$1990^{53} \quad$ birth and plasma derived vaccine $5 \mu \mathrm{g}$ at $200 \mathrm{IU}$ at birth and plasma 2 days and 1,2 , and 12 months derived vaccine $2 \mu \mathrm{g}$ at 2 days and 1,2 , and 12 months

Xu 1995 5 A: $16 \mu \mathrm{g}$ plasma derived vaccine-1 at $\quad$ B: $20 \mu \mathrm{g}$ plasma derived birth and at 1 and 6 months. C: Hepatitis vaccine-2 at birth and at 1 and B immunoglobulin $250 \mathrm{IU}$ at birth and 206 months. D: Vaccine diluent $\mu \mathrm{g}$ plasma derived vaccine-2 at birth and plus adjuvant at birth and at 1 at 1 and 6 months

\begin{tabular}{lll}
\hline Yeoh $1986^{58}$ & A: Mothers positive for hepatitis B & B: Mothers positive for hepatitis
\end{tabular} surface antigen and positive for hepatitis B surface antigen and positive B e antigen (150 infants): Hepatitis B for hepatitis B e antigen (150 immunoglobulin $0.5 \mathrm{ml}$ at birth and infants): Hepatitis $B$ plasma derived vaccine $10 \mu \mathrm{g}$ at birth and immunoglobulin $0.5 \mathrm{ml}$ at birth at 1 and 6 months. C: Mothers positive and recombinant vaccine $5 \mu \mathrm{g}$ for hepatitis B surface antigen and at birth and at 1 and 6 months. negative for hepatitis $B$ e antigen mothers $\quad D$ : Mothers positive for hepatitis (150 infants). Hepatitis B immunoglobulin B surface antigen and negative $0.5 \mathrm{ml}$ at birth and plasma derived

vaccine $10 \mu \mathrm{g}$ at birth and at 1 and $6 \quad$ infants). Hepatitis B months

immunoglobulin $0.5 \mathrm{ml}$ at birth and recombinant vaccine $5 \mu \mathrm{g}$ at birth and at 1 and 6 months $\mu \mathrm{g}$ at birth and at 1 month and $10 \mu \mathrm{g}$ recombinant vaccine- 1 at 2 and 12 months birth, 1 and 6 months

\begin{tabular}{lll}
\hline Zhu $1987^{60}$ & $\begin{array}{l}\text { A: } 16 \mu \mathrm{g} \text { vaccine given at birth, } 1 \text { and } 6 \\
\text { months }\end{array}$ & $\begin{array}{l}\text { B: Buffer of vaccine given at } \\
\text { birth, } 1 \text { and } 6 \text { months }\end{array}$ \\
\hline Zhu $1994^{59}$ & $\begin{array}{l}\text { A: Recombinant vaccine } 20 \mu \mathrm{g} \text { at birth } \\
\text { and at } 1 \text { and } 6 \text { months }\end{array}$ & $\begin{array}{l}\text { B: Plasma derived vaccine } 20 \\
\mu \mathrm{g} \text { at birth and at } 1 \text { and } 6 \\
\text { months }\end{array}$ \\
\hline
\end{tabular}


Table 2 Reported methodological quality of included randomised clinical trials assessing effects of hepatitis $B$ vaccines and immunoglobulin for newborn infants of mothers positive for hepatitis B surface antigen

\begin{tabular}{|c|c|c|c|c|}
\hline Trial & $\begin{array}{l}\text { Generation of } \\
\text { allocation } \\
\text { sequence }\end{array}$ & $\begin{array}{l}\text { Allocation } \\
\text { concealment }\end{array}$ & Blinding & $\begin{array}{l}\text { Methodological } \\
\text { quality }\end{array}$ \\
\hline $\begin{array}{l}\text { Assateerawatt } \\
1993^{23}\end{array}$ & Adequate & Unclear & Not done & Low \\
\hline Beasley $1983^{724}$ & Unclear & Unclear & Unclear & Low \\
\hline Beasley $1983^{25}$ & Unclear & Unclear & Unclear & Low \\
\hline Farmer $1987^{26}$ & Adequate & Unclear & Not done & Low \\
\hline Garcia $1992^{27}$ & Unclear & Unclear & Unclear & Low \\
\hline Grosheide $1993^{29}$ & Unclear & Adequate & Not done & Low \\
\hline Halliday $1992^{30}$ & Adequate & Adequate & Adequate & High $^{*}$ \\
\hline Hieu $2002^{31}$ & Adequate & Adequate & Not done & High $^{*}$ \\
\hline Ip $1989^{32} 3354$ & Unclear & Adequate & Adequate & High $^{*}$ \\
\hline Kang $1995^{34}$ & Unclear & Unclear & Not done & Low \\
\hline Khukhlovich $1996^{35}$ & Unclear & Unclear & Unclear & Low \\
\hline Kuru $1995^{36}$ & Unclear & Unclear & Not reported & Low \\
\hline Lee $1995^{37-39}$ & Unclear & Unclear & Not done & Low \\
\hline Liu $1987^{40}$ & Unclear & Adequate & Adequate & High $^{*}$ \\
\hline Lo $1985^{2841}$ & Unclear & Unclear & Not done & Low \\
\hline Lolekha $2002^{42}$ & Unclear & Unclear & Not done & Low \\
\hline Oon $1986^{43}$ & Adequate & Unclear & Not done & Low \\
\hline Piazza $1985^{44}$ & Adequate & Adequate & Unclear & High $^{*}$ \\
\hline Pongpipat $1986^{45}$ & Unclear & Unclear & Not done & Low \\
\hline Pongpipat $1988^{46}$ & Unclear & Unclear & Not done & Low \\
\hline Pongpipat $1989^{47}$ & Unclear & Unclear & Not done & Low \\
\hline $\begin{array}{l}\text { Poovorawan } 1997^{48} \\
49\end{array}$ & Unclear & Unclear & Not done & Low \\
\hline Sehgal $1992^{5051}$ & Unclear & Unclear & Not done & Low \\
\hline Theppisai $1987^{52}$ & Unclear & Unclear & Not done & Low \\
\hline Theppisai $1990^{53}$ & Unclear & Unclear & Not done & Low \\
\hline Xu $1995^{55-57}$ & Unclear & Unclear & Unclear & Low \\
\hline Yeoh $1986^{58}$ & Unclear & Unclear & Not done & Low \\
\hline Zhu $1987^{60}$ & Unclear & Unclear & Unclear & Low \\
\hline Zhu $1994^{59}$ & Unclear & Unclear & Not done & Low \\
\hline
\end{tabular}

* Trials having low risk of bias.

\section{Hepatitis B immunoglobulin versus placebo or no} intervention

Overall, hepatitis B immunoglobulin significantly decreased the risk of hepatitis $\mathrm{B}$ occurrence in infants $(0.52,0.44$ to $0.63 ; 11$ trials) (fig 4). Compared with placebo or no intervention, hepatitis B immunoglobulin alone significantly reduced hepatitis B occurrence $(0.50,0.41$ to 0.60 ; one trial). Compared with vaccination, vaccination plus hepatitis $B$ immunoglobulin significantly reduced hepatitis $\mathrm{B}$ occurrence $(0.54,0.41$ to 0.73 ; 10 trials). The sensitivity analyses for drop outs were consistent, indicating the robustness of the findings. In the metaregression analyses, none of the trial characteristics (methodological quality, dosage of hepatitis B immunoglobulin, or time of hepatitis B immunoglobulin injection) was significantly associated with the effect of hepatitis $\mathrm{B}$ immunoglobulin $(\mathrm{P}=0.92, \mathrm{P}=0.67$, and $\mathrm{P}=0.79$, respectively). Subgroup analyses did not show a significant difference between high quality and low quality trials, the mother's hepatitis B e antigen status, or time of hepatitis B immunoglobulin injection (tests for interaction, $\mathrm{P}=0.70,0.62$, and 0.63 , respectively).

Hepatitis B immunoglobulin did not significantly reduce the number of infants with antibody levels to hepatitis B surface antigen $<10 \mathrm{IU} / 1$ ( $1.55,0.89$ to 2.73 ; four trials).

Few trials reported adverse events. If reported, the authors did not specify in which intervention group they occurred. A meta-analysis on adverse events could not, therefore, be carried out. In one trial, ${ }^{24}$ one infant who received hepatitis B immunoglobulin died. The death seemed to be unrelated to the immunoglobulin.

Neither funnel plot on hepatitis B occurrence showed asymmetry (Egger test, $\mathrm{P}=0.31$; Begg test, $\mathrm{P}=0.23$ ).

\section{Multiple versus single injection of hepatitis B \\ immunoglobulin}

Multiple hepatitis B immunoglobulin plus plasma derived vaccine versus single hepatitis B immunoglobulin injection plus plasma derived vaccine did not significantly reduce the risk of hepatitis B occurrence $\left(0.87,0.30\right.$ to 2.47 ; two trials, $\left.\mathrm{I}^{2}=0 \%\right)$.

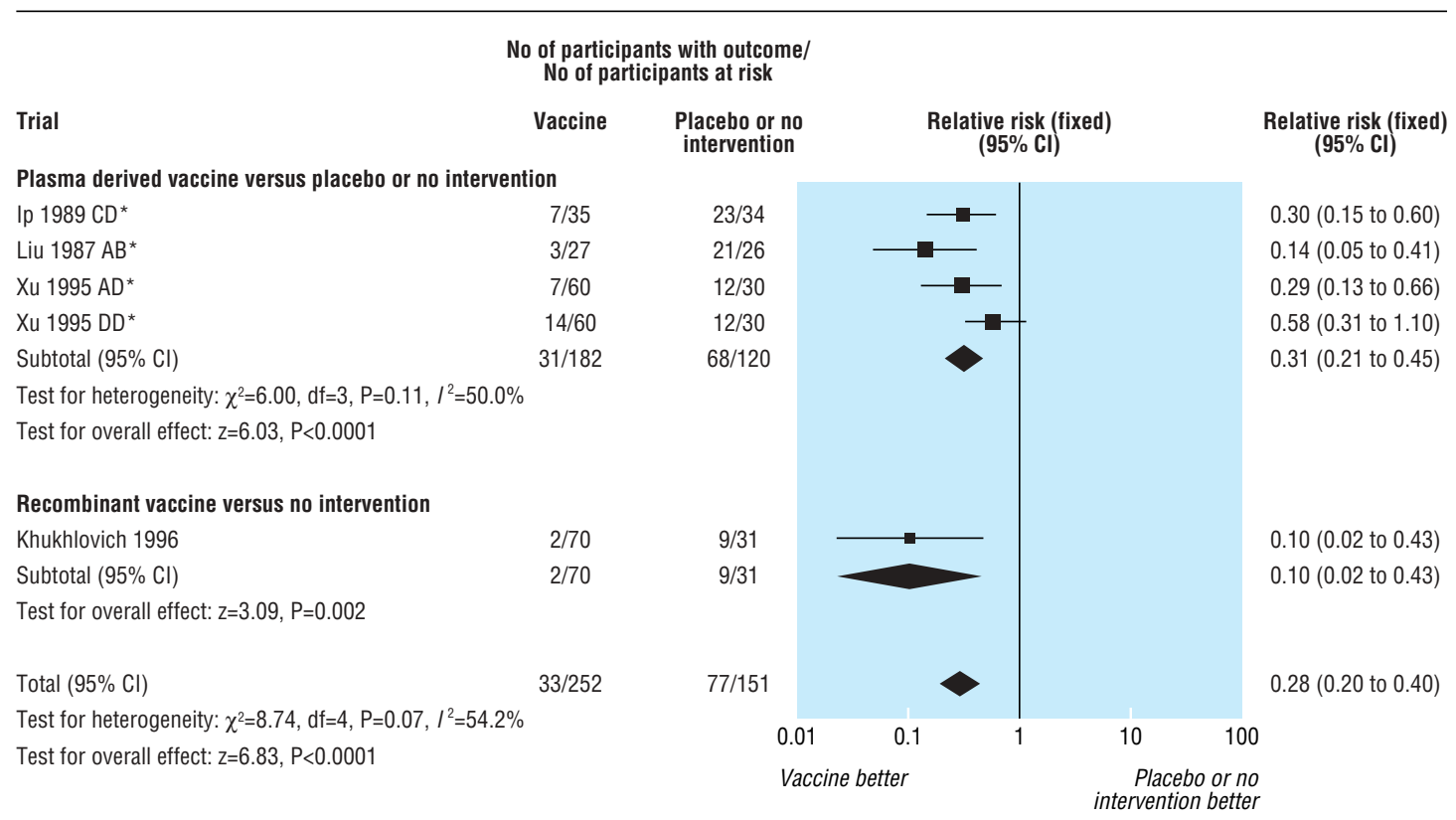

Fig 2 Effect of hepatitis B vaccine on occurrence of hepatitis B in newborn infants. * Experimental and control groups (see table 1 for definitions) 
Vaccination plus hepatitis B immunoglobulin versus placebo or no intervention

Compared with placebo or no intervention, plasma derived vaccine plus hepatitis B immunoglobulin significantly reduced hepatitis B occurrence $(0.08,0.03$ to 0.17 ; three trials) (fig 5$)$. The sensitivity analyses confirmed the robustness of the finding. Subgroup analyses did not find a significant difference between high quality and low quality trials, the mother's hepatitis B e antigen status, or time of hepatitis B immunoglobulin injection (tests for interaction, $\mathrm{P}=0.13, \mathrm{P}=0.28$, and $\mathrm{P}=0.22$, respectively).

One trial reported the number of adverse events: three out of 71 infants given vaccination compared with five out of 34 in the control group. ${ }^{32}$ The results showed no significant difference $(0.29,0.07$ to 1.13 ; one trial).

\section{Discussion}

Our systematic reviews shows that hepatitis B vaccine, hepatitis B immunoglobulin, or the combination of vaccine plus immunoglobulin given to the newborn infants of mothers positive for hepatitis B surface antigen prevents the occurrence of hepatitis B. Furthermore, the combination of vaccine plus immunoglobulin was superior to vaccine alone. These benefits were not significantly associated with the methodological quality of the trials, the mother's hepatitis B e antigen status, time of injection, or number of infants dropping out of the study.

Our review has several potential limitations. Firstly, some analyses include few trials and a small number of newborn infants. Secondly, most trials were of low methodological quality. We did not, however, find a strong association between methodological quality and results. This supports the robustness of our results, but does not exclude the possibility of bias. ${ }^{61-63}$ Thirdly, although we did not find asymmetries in funnel plots, we cannot exclude publication bias. Fourthly, only a few investigators responded to our request for further information and often that the details were lost. Fifthly, most trials reported only surrogate outcomes (hepatitis B surface antigen status or antibody levels to hepatitis B surface antigen) and not long term clinical outcomes. One trial with long term follow-up did find more patients with chronic hepatitis in the plasma derived vaccine plus hepatitis B immunoglobulin group compared with the plasma derived vaccine group. ${ }^{32}$

Our results show that hepatitis $\mathrm{B}$ vaccination prevents the occurrence of hepatitis B in the newborn infants of mothers positive for hepatitis B surface antigen. We found no significant difference between recombinant vaccine and plasma derived vaccine on hepatitis B infections (relative risk 1.00, 95\% CI 0.70 to 1.42). However, more infants who received recombinant vaccine achieved antibody levels to hepatitis surface antigen $>10 \mathrm{IU} / \mathrm{l}$ (1.96, 1.39 to 2.78$)$. The advantage of recombinant vaccine might be due to the difference in chemical and physical characteristics of the antigen components of the vaccines. ${ }^{64}$ Recombinant vaccine is used in high income countries owing to the fear of acquiring human immunodeficiency virus and other infections, including transmissible spongiform encephalopathies. ${ }^{65}$ Our finding seems to support the introduction of recombinant vaccines in clinical practice.

The recommended schedules for immune prophylaxis against hepatitis $\mathrm{B}$ varies among countries. ${ }^{667}$ In general we were unable to show significant differences among different doses, different schedules, and different forms of plasma derived vaccine and recombinant vaccine on hepatitis $\mathrm{B}$ occurrence. Furthermore, our subgroup analyses did not show a strong association between timing of injection (within 12, 24, or 48 hours) and magnitude of effects. The number of infants evaluated in these comparisons was small. Therefore larger trials are needed before equivalence or non-inferiority can be claimed.

Our meta-analyses found that hepatitis B immunoglobulin alone or when added to hepatitis B vaccine decreased the risk of hepatitis $\mathrm{B}$ infection $(0.52,0.44$ to 0.63$)$. A recent nonrandomised study reported no benefit of adding hepatitis B immunoglobulin to vaccine in mothers negative for hepatitis B e antigen. ${ }^{68}$ In our analysis, only one small trial out of 11 trials included infants of such mothers. ${ }^{55}$ Our subgroup analysis did

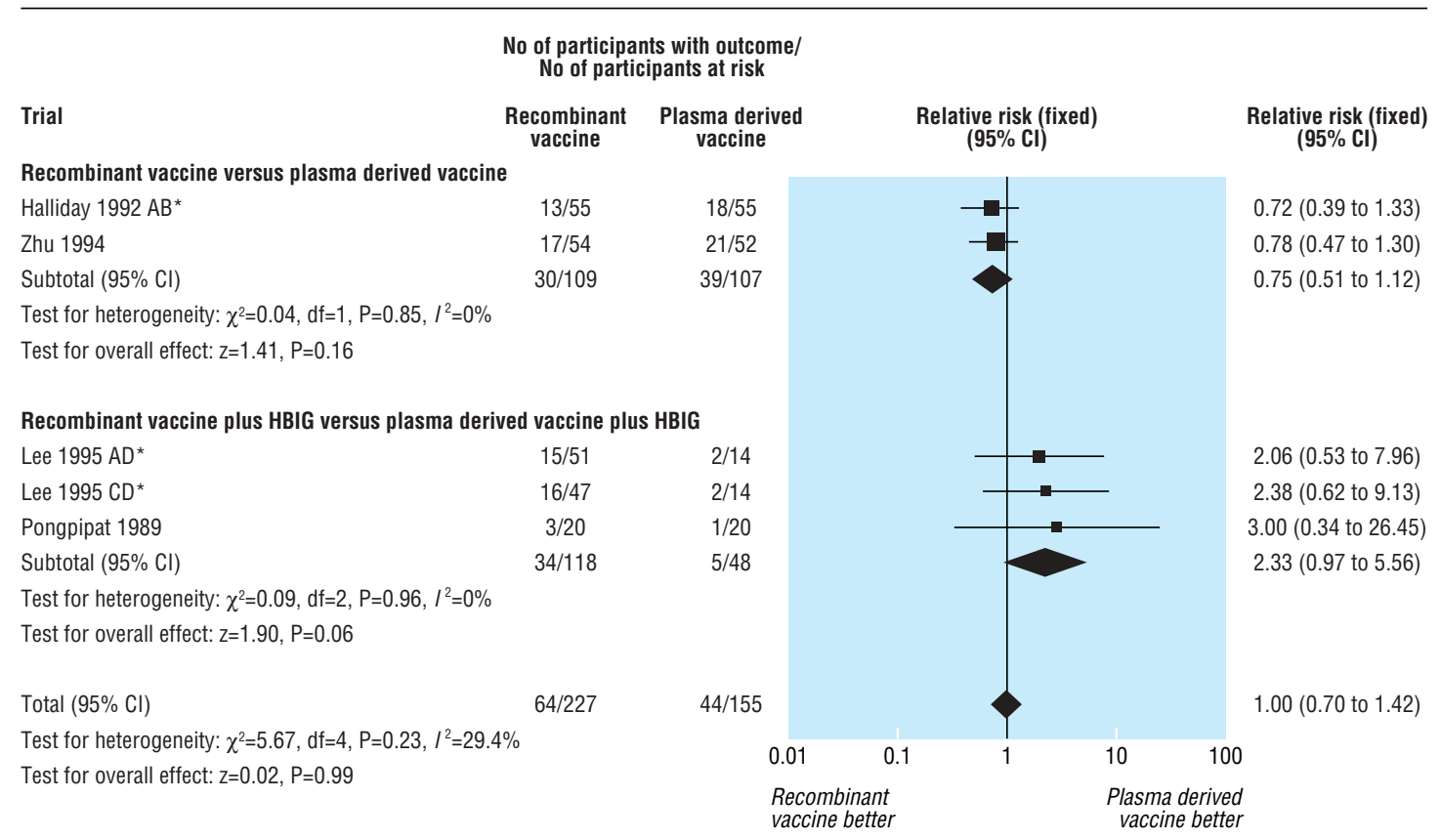

Fig 3 Effect of recombinant vaccine compared with plasma derived vaccine on occurrence of hepatitis B in newborn infants. HBIG=hepatitis B immunoglobulin *Experimental and control groups (see table 1 for definitions) 
not find any statistically significant difference between infants of mothers negative or positive for hepatitis $\mathrm{B}$ e antigen. More randomised trials seem warranted on the addition of hepatitis $\mathrm{B}$ immunoglobulin to vaccine for infants of mothers negative for hepatitis B e antigen. It should be noted that hepatitis B immunoglobulin, as with plasma derived vaccine, has the potential for transmission of bloodborne infections. ${ }^{69}$
Few trials reported sufficiently on adverse events. According to what was reported, hepatitis B vaccine and hepatitis B immunoglobulin seem safe. These results are in accordance with two Cochrane reviews on hepatitis B vaccination of healthcare workers and dialysis patients. ${ }^{70} 71$ Furthermore, cohort studies found that hepatitis B vaccination is well tolerated and that severe adverse events are rare. ${ }^{72-79}$ One cohort study did find, however,

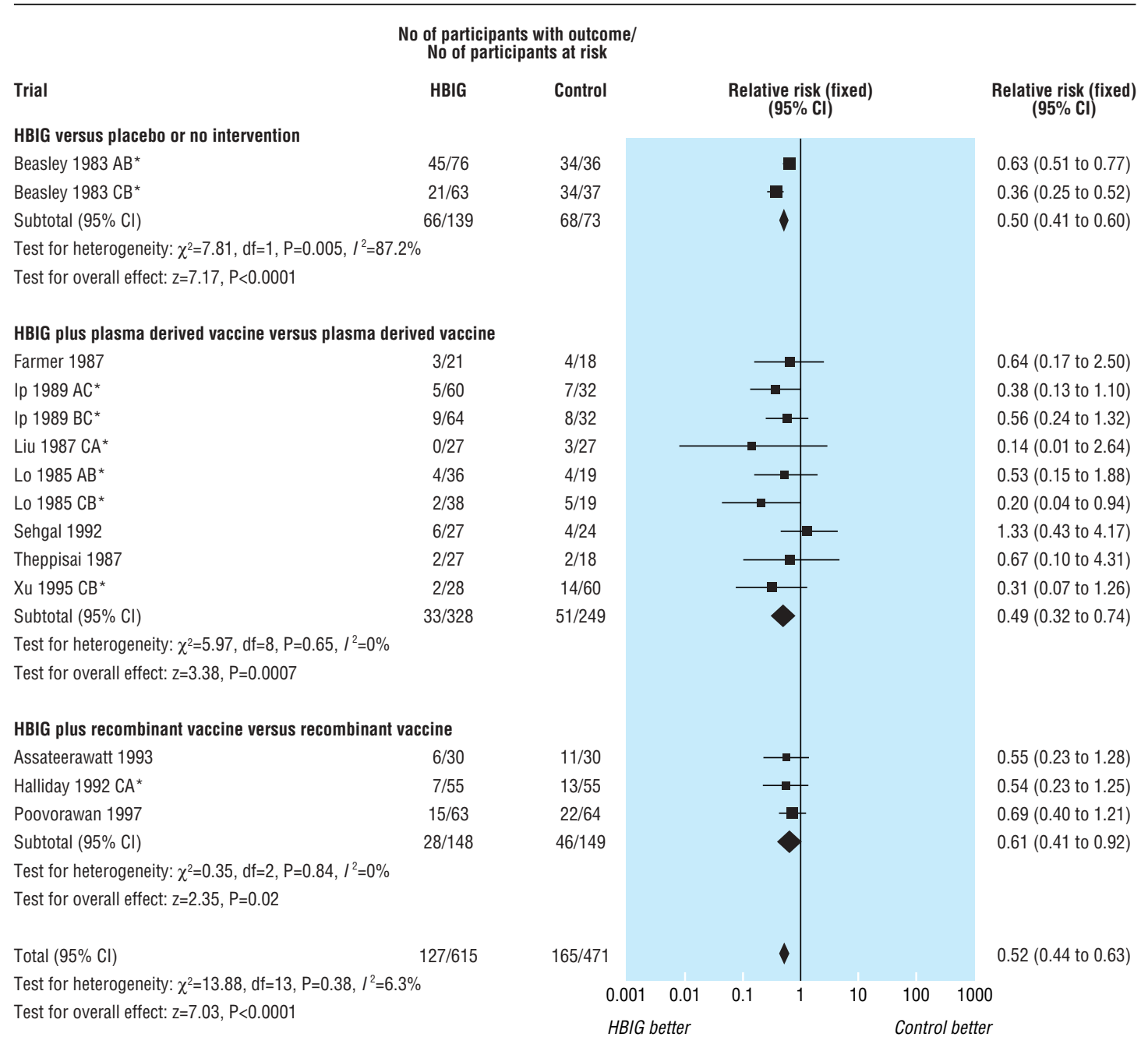

Fig 4 Effect of hepatitis B immunoglobulin (HBIG) on occurrence of hepatitis B in newborn infants. *Experimental and control groups (see table 1 for definitions)

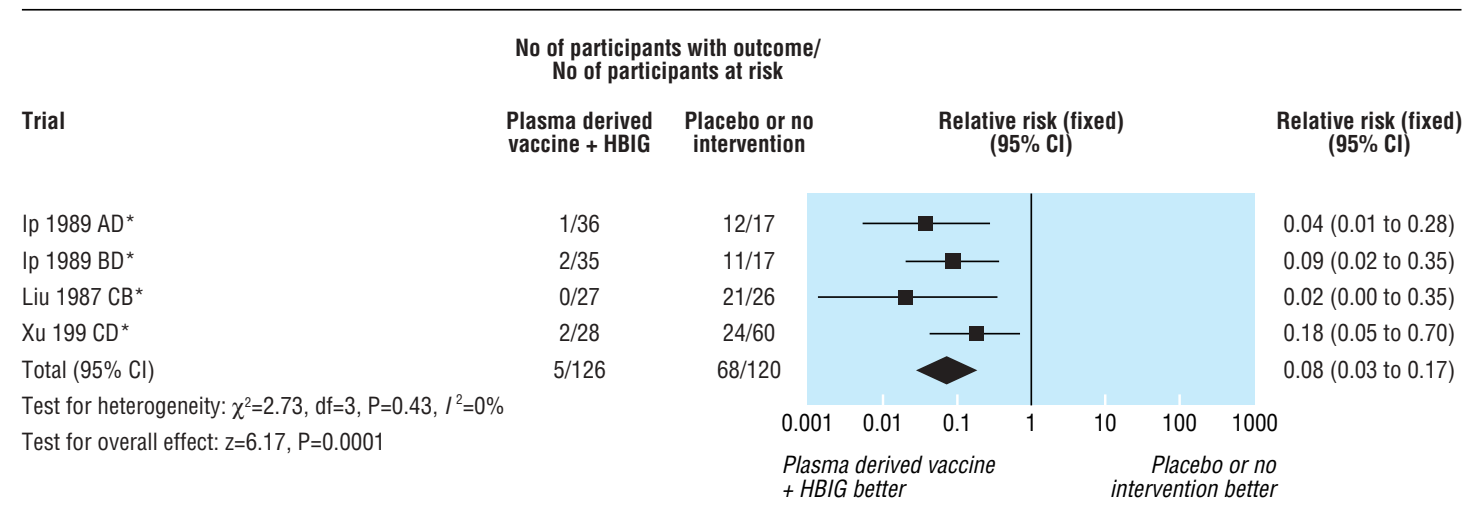

Fig 5 Effect of plasma derived vaccine and hepatitis B immunoglobulin (HBIG) on occurrence of hepatitis B in newborn infants. *Experimental and control groups (see table 1 for definitions) 


\section{What is already known on this topic}

Mother to child transmission accounts for up to $50 \%$ of hepatitis B carriers

Repeated vaccination over months is required to mount an effective antibody response

Immunoglobulin is immediately effective and seems protective for several months, after which it wanes

\section{What this study adds}

Vaccine decreased the risk of hepatitis B infection among infants of mothers positive for hepatitis B surface antigen

Immunoglobulin alone or added to vaccine decreased the risk of hepatitis B infection among infants of mothers positive for hepatitis B surface antigen

Evidence on immunisation for infants of mothers positive for hepatitis B surface antigen but negative for hepatitis B e antigen is weak

that hepatitis B vaccine increased the risk of chronic arthritis and acute ear infections. ${ }^{80}$ We are unable to determine if the reliability of this finding owing to the methodological weaknesses of cohort studies ${ }^{66}$ Randomised clinical trials may overlook adverse events because of the relatively low numbers of participants or poor reporting of adverse events. ${ }^{81-83}$ Further trials ought to focus on adverse events after the International Conference on Harmonisation's guidelines for clinical trials. ${ }^{79}$

In general, the risk of perinatal transmission from mothers negative for hepatitis B e antigen is considered much lower than that from mothers who are positive for the antigen..$^{5-9}$ Further, the infants of hepatitis B e antigen negative mothers often clear an asymptomatic infection. ${ }^{15}$ Our findings are mainly based on immune prophylaxis for infants of mothers positive for hepatitis $\mathrm{B}$ surface antigen and hepatitis B e antigen. Evidence from randomised clinical trials is insufficient to either support or refute immune prophylaxis for infants of mothers negative for hepatitis B e antigen. The applicability of our findings to mothers negative for hepatitis B e antigen, which are of high proportions in, for example, the United States and northern Europe, is therefore limited ${ }^{84}$ Cost effectiveness studies indicate that hepatitis B vaccination for infants of mothers positive for hepatitis B surface antigen are cost effective in countries with low, ${ }^{85-88}$ intermediate, and high prevalence. ${ }^{89-92}$ We identified no cost effectiveness studies assessing the effects of adding hepatitis B immunoglobulin to vaccine. As hepatitis $\mathrm{B}$ immunoglobulin may reduce the risk of hepatitis $B$ infection, the need to carry out cost effectiveness studies based on randomised trials seems justified.

Two trials that discussed a new way to potentially prevent vertical transmission of hepatitis B did not fulfil our inclusion criteria. ${ }^{14}$ The two trials randomised pregnant women positive for hepatitis B surface antigen to hepatitis B immunoglobulin versus no intervention before delivery. ${ }^{93}{ }^{94}$ In the group receiving immunoglobulin, fewer infants were positive for hepatitis B surface antigen at follow-up. The methodological quality of those trials was low. Furthermore, the mothers are at risk of developing immune complex disease due to hepatitis B immunoglobulin reacting with their own circulating hepatitis B surface antigens. More trials are therefore needed before this intervention should be adopted.
We thank TO Jefferson, M Pratt, J Buttery, and N El-Shukri who participated in the formulation of the first Cochrane protocol on this topic; D Nikolova, the Cochrane Hepato-Biliary Group, for translating a Russian trial and retrieving articles; D Haughton, the Cochrane Neonatal Review Group, for retrieving articles; Y Poovorawan and M Piazza who clarified information on their trials; A Dutta, MM Hassan, and SD Lee for providing assistance in our work to identify trial authors, and JU Olsen, GlaxoSmithKline, Denmark, for providing information on randomised clinical trials. This systematic review was carried out using the recommendations of the Cochrane Collaboration and the Cochrane Hepato-Biliary Group. This review will be published as a Cochrane review in the Cochrane Library. Cochrane reviews are regularly updated as new evidence emerges and in response to comments and criticisms. The Cochrane Library should be consulted for the most recent version of the review.

Contributors: CL developed the search strategy, identified trials, extracted data, carried out the statistical analyses, and drafted parts of the review. YG extracted data, carried out the statistical analyses, drafted parts of the review, and revised the review. YG is the guarantor. JB validated the assessment of methodological quality of the included trials, validated data from six randomly selected trials, drafted parts of the review, and revised the review. EHB has research experience in this topic. She provided trials for this review, validated data extraction, and revised the review. CG coordinated the review, functioned as an adjudicator in cases of disagreement, drafted parts of the review, and revised the review.

Funding: Tri-Service General Hospital, Taiwan; Copenhagen Trial Unit, Copenhagen University Hospital, Denmark; SC Van Foundation, Denmark; and Public Health Laboratory Service, United Kingdom.

Competing interests: None declared.

Ethical approval: Not required.

1 Beasley RP, Hwang LY. Hepatocellular carcinoma and hepatitis B virus. Semin Liver Dis 1984;4:113-21.

Yao JL. Perinatal transmission of hepatitis B virus infection and vaccination in China Gut 1996;38(suppl 2):S37-8.

3 Stevens CE, Beasley RP, Tsui J, Lee WC. Vertical transmission of hepatitis B antigen in Taiwan. NEngl J Med 1975;292:771-4.

4 Akhter S, Talukder MQ Bhuiyan N, Chowdhury TA, Islam MN, Begum S. Hepatitis B virus infection in pregnant mothers and its transmission to infants. Indian J Pediatr 1992;59:411-5.

5 Okada K, Kamiyama I, Inomata M, Imai M, Miyakawa Y. E antigen and anti-e in the serum of asymptomatic carrier mothers as indicators of positive and negative transmission of hepatitis B virus to their infants. N Engl J Med 1976;294:746-9.

6 Beasley RP, Trepo C, Stevens CE, Szmuness W. The e antigen and vertical transmission of hepatitis B surface antigen. Am J Epidemiol 1977;105:94-8.

7 Beasley RP, Hwang LY, Lee GC, Lan CC, Roan CH, Huang FY, et al. Prevention of perinatally transmitted hepatitis B virus infections with hepatitis B immune globulin and hepatitis B vaccine. Lancet 1983;2:1099-102.

8 Nayak NC, Panda SK, Zuckerman AJ, Bhan MK, Guha DK. Dynamics and impact of perinatal transmission of hepatitis B virus in north India. J Med Virol 1987;21:137-45.

perinatal transmission of hepatitis B virus in north India. J Med Virol 1987;21:137-45.
Aggarwal R, Ranjan P. Preventing and treating hepatitis B infection. BMJ 2004;329:1080-6.

10 Assad S, Francis A. Over a decade of experience with a yeast recombinant hepatitis B vaccine. Vaccine 1999;18:57-67.

11 Beasley RP, Hwang LY. Postnatal infectivity of hepatitis B surface antigen-carrier mothers. J Infect Dis 1983;147:185-90.

12 Nair PV, Weissman JY, Tong MJ, Thursby MW, Paul RH, Henneman CE. Efficacy of hepatitis B immune globulin in prevention of perinatal transmission of the hepatitis B virus. Gastroenterology 1984;87:293-8.

13 Alderson P, Green S, Higgins J. Cochrane reviewers' handbook 4.2.2 [updated March 2004]. In: Cochrane Library. Chichester, UK: Wiley, 2004.

14 Lee C, Gong Y, Brok J, Boxall EH, Gluud C. Hepatitis B prophylaxis for newborns of hepatitis B surface antigen-positive mothers [protocol for a Cochrane review]. Cochrane Database Syst Rev 2004;(2):CD004790.

15 Dusheiko G. Hepatitis B. In: Bircher J, Benhamou JP, McIntyre N, Rizzetto M, Rodés J, eds. Oxford textbook of clinical hepatology. Oxford: Oxford Medical Publications, 1998:876-96.

16 Szmuness W, Stevens CE, Zang EA, Harley EJ, Kellner A. A controlled clinical trial of the efficacy of the hepatitis B vaccine (Heptavax B): a final report. Hepatology 1981:1:377-85.

17 Hadler SC, Francis DP, Maynard JE, Thompson SE, Judson FN, Echenberg DF, et al. Long-term immunogenicity and efficacy of hepatitis B vaccine in homosexual men. $N$ Engl J Med 1986;315:209-14.

18 Higgins JP, Thompson SG. Quantifying heterogeneity in a meta-analysis. Stat Med 2002;21:1539-58.

19 Altman DG, Bland JM. Interaction revisited: the difference between two estimates. BMJ 2003;326:219.

20 Hollis S, Campbell F. What is meant by intention to treat analysis? Survey of published randomised controlled trials. BMJ 1999;319:670-1.

21 Begg CB, Mazumdar M. Operating characteristics of a rank correlation test for publication bias. Biometrics 1994;50:1088-101.

22 Egger M, Davey SG, Schneider M, Minder C. Bias in meta-analysis detected by a simple, Egger M, Davey SG, Schneider M, Min
graphical test. BMJ 1997;315:629-34.

23 Araphical test. BMJ 1997;315:629-34. 23 Assateerawatt A, Tanphaichitr VS, Suvatte V, Yodthong S. Immunogenicity and efficacy
of a recombinant DNA hepatitis B vaccine, GenHevac B Pasteur in high risk neonates, school children and healthy adults. Asian Pac J Allergy Immunol 1993;11:85-91. 
24 Beasley RP, Hwang LY, Stevens CE, Lin CC, Hsieh FJ, Wang KY, et al. Efficacy of hepatitis B immune globulin for prevention of perinatal transmission of the hepatitis B virus carrier state: final report of a randomized double-blind, placebo-controlled trial. Hepatology 1983;3:135-41.

25 Beasley RP, Hwang LY, Szmuness W, Stevens CE, Lin CC, Hsieh FJ, et al. HBIG prophylaxis for perinatal HBV infections-final report of the Taiwan trial. Dev Bio Stand 1983;54:363-75.

26 Farmer K, Gunn T, Woodfield DG. A combination of hepatitis B vaccine and immunoglobulin does not protect all infants born to hepatitis B e antigen positive mothers. N Z Med J 1987;100:412-4.

27 Garcia EG, Gonzalez JRB, Guillot CC, Curbelo GT, Griego AG, Gonzalez MGD. [Field trial of the Cuban recombinant vaccine against hepatitis B (Heberbiovac HB). Study in newborn infants born to AgsHB+ mothers]. Rev Cubana Med Trop 1992;44:149-57.

28 Goudeau A, Lo KJ, Coursaget P, Tong MJ, Yeh CL, Tsai YT, et al. Prevention of hepatitis B virus infection in children born to HBsAg positive/HBeAg positive mothers. Preliminary results of active and passive-active immunization. Dev Biol Stand 1983;54:399404.

29 Grosheide PM, del Canho R, Heijtink RA, Nuijten AS, Zwijnenberg J, Banffer JR, et al. Passive-active immunization in infants of hepatitis Be antigen-positive mothers. Comparison of the efficacy of early and delayed active immunization. Am J Dis Child 1993;147:1316-20.

30 Halliday ML, Kang LY, Rankin JG, Coates RA, Corey PN, Hu ZH, et al. An efficacy trial of a mammalian cell-derived recombinant DNA hepatitis B vaccine in infants born to mothers positive for HBsAg, in Shanghai, China. Int J Epidemiol 1992;21:564-73.

31 Hieu NT, Kim KH, Janowicz Z, Timmermans I. Comparative efficacy, safety and immunogenicity of Hepavax-Gene and Engerix-B, recombinant hepatitis B vaccines, in infants born to HBsAg and HBeAg positive mothers in Vietnam: an assessment at 2 years. Vaccine 2002;20:1803-8.

32 Ip HM, Lelie PN, Wong VC, Kuhns MC, Reesink HW. Prevention of hepatitis B virus carrier state in infants according to maternal serum levels of HBV DNA. Lancet 1989;1:406-10.

33 Ip HM, Wong VC, Lelie PN, Reesink HW, Schaasberg W, Yeung CY, et al. Hepatitis B infection in infants after neonatal immunization. Acta Paediatr Jpm 1989;31:654-8.

34 Kang P, Shen XM, Yu HM. [Study on the efficacy of genetically engineered vaccines against hepatitis B for interruption of perinatal transmission]. Zhonghua Hu Li Za Zhi 1995;30:390-2

35 Khukhlovich PA, Shakhgil'dian IV, Narkevich MI, Anan'ev VA, Kuzin SN, Sergeeva NA, et al. [The vaccinal prophylaxis of hepatitis B among children born to mothers with persistent HBs-antigenemia]. Zh Mikrobiol Epidemiol Immunobiol 1996;55-9.

36 Kuru U, Turan O, Kuru N, Saglam Z, Alver A. Results of vaccinated infants born to HBsAg-positive mothers with different hepatitis B vaccines and doses. Turk J Pediatr 1995;37:93-102.

37 Lee CY, Huang LM, Chang MH, Hsu CY, Wu SJ, Sung JL, et al. The protective efficacy of recombinant hepatitis $B$ vaccine in newborn infants of hepatitis B e antigen-positive-hepatitis B surface antigen carrier mothers. Pediatr Infect Dis $J$ 1991;10:299-303.

38 Lee PI, Lee CY, Huang LM, Chang MH. Long-term efficacy of recombinant hepatitis B vaccine and risk of natural infection in infants born to mothers with hepatitis B e antigen. J Pediatr 1995;126:716-21.

39 Lee PI, Lee CY, Huang LM, Chen JM, Chang MH. A follow-up study of combined vaccination with plasma-derived and recombinant hepatitis B vaccines in infants. Vaccine 1995;13:1685-9.

$40 \mathrm{Liu} \mathrm{LH}$. [Comparative study of the efficacy of hepatitis B virus (HBV) vaccine combined with hepatitis B immunoglobulin (HBIG) versus vaccine alone in the interruption of the perinatal transmission of HBV carrier state]. Zhonghua Liu Xing Bing ruption of the perinatal

41 Lo KJ, Tsai YT, Lee SD, Yeh CL, Wang JY, Chiang BN, et al. Combined passive and active immunization for interruption of perinatal transmission of hepatitis $\mathrm{B}$ virus in Taiwan. Hepatogastroenterology 1985;32:65-8.

42 Lolekha S, Warachit B, Hirunyachote A, Bowonkiratikachorn P, West DJ, Poerschke G. Protective efficacy of hepatitis B vaccine without HBIG in infants of HBeAg-positive carrier mothers in Thailand. Vaccine 2002;20:3739-43.

43 Oon CJ, Tan KL, Goh KT, Wong-Yong L, Viegas O, McCarthy T, et al. Evaluation of a low dose of hepatitis $\mathrm{B}$ vaccine given within a childhood immunisation programme in Singapore. J Infect 1986;13:255-67.

44 Piazza M, Picciotto L, Villari R, Guadagnino V, Orlando R, Isabella L, et al. Hepatitis B immunisation with a reduced number of doses in newborn babies and children. Lancet 1985;1:949-51.

45 Pongpipat D, Suvatte V, Assateerawatts A. Efficacy of hepatitis-B immunoglobulin and hepatitis-B vaccine in prevention of the HBsAg carrier state in newborn infants of mothers who are chronic carriers of HBsAg and HBeAg. Asian Pac J Allergy Immuno 1986;4:33-6.

46 Pongpipat D, Suvatte V, Assateerawatts A. Hepatitis B immunization in high risk neonates born from $\mathrm{HBsAg}$ and $\mathrm{HBeAg}$ positive mothers: comparison of standard and low dose regimens. Asian Pac J Allergy Immunol 1988;6:107-10.

47 Pongpipat D, Suvatte V, Assateerawatts A. Hepatitis B immunization in high risk neonates born from HBsAg positive mothers: comparison between plasma derived neonates born from HBsAg positive mothers: comparison between pla

48 Poovorawan Y, Sanpavat S, Chumdermpadetsuk S, Safary A. Long-term hepatitis B vaccine in infants born to hepatitis B e antigen positive mothers. Arch Dis Child Fetal Neonatal Ed 1997;77:F47-51.

49 Poovorawan Y, Sanpavat S, Pongpunglert W, Chumdermpadetsuk S, Sentrakul P, Vandepapeliere P, et al. Long term efficacy of hepatitis B vaccine in infants born to hepatitis B e antigen-positive mothers. Pediatr Infect Dis J 1992;11:816-21.

50 Sehgal A, Gupta I, Sehgal R, Ganguly NK. Hepatitis B vaccine alone or in combination with anti-HBs immunoglobulin in the perinatal prophylaxis of babies born to HBsAg carrier mothers. Acta Virol 1992:36:359-66.

51 Sehgal A, Sehgal R, Gupta I, Bhakoo ON, Ganguly NK. Use of hepatitis B vaccine alone or in combination with hepatitis B immunoglobulin for immunoprophylaxis of perinatal hepatitis B infection.J Trop Pediatr 1992;38:247-51.

52 Theppisai U, Thanuntaseth C, Chiewsilp P, Siripoonya P. A comparison between the efficacy of passive-active and active immunization for prevention of perinatal transmission of hepatitis B virus.J Med Assoc Thai 1987;70:459-62.
53 Theppisai U, Thanuntaseth C, Chiewsilp P, Siripoonya P. Prevention of hepatitis B infection in infants born to hepatitis B carrier mothers: low dosage vaccination. Int J Gynaecol Obstet 1990;32:353-7.

54 Wong VC, Ip HM, Reesink HW, Lelie PN, Reerink-Brongers EE, Yeung CY, et al. Prevention of the HBsAg carrier state in newborn infants of mothers who are chronic carriers of $\mathrm{HBsAg}$ and $\mathrm{HBeAg}$ by administration of hepatitis-B vaccine and hepatitis-B immunoglobulin. Double-blind randomised placebo-controlled study. Lancet 1984;1:921-6.

55 Xu ZY, Duan SC, Margolis HS, Purcell RH, Ou-Yang PY, Coleman PJ, et al. Long-term efficacy of active postexposure immunization of infants for prevention of hepatitis B virus infection. United States-People's Republic of China Study Group on Hepatitis B. J Infect Dis 1995;171:54-60.

56 Xu ZY, Francis DP, Liu CB, Purcell RH, Duan SC, Chen RJ, et al. Prevention of hepatitis B virus carriage of infants using $\mathrm{HBV}$ vaccine in Shanghai. Preliminary report of a randomized double-blind placebo-controlled trial. Chin Med J (Engl) 1985;98:623-6.

57 Xu ZY, Liu CB, Francis DP, Purcell RH, Gun ZL, Duan SC, et al. Prevention of perinatal acquisition of hepatitis B virus carriage using vaccine: preliminary report of a randomized, double-blind placebo-controlled and comparative trial. Pediatrics $1985 ; 76: 713-8$.

58 Yeoh EK, Chang WK, Ip P, Chan KH, Chan E, Fung C. Efficacy and safety of recombinant hepatitis B vaccine in infants born to HBsAg-positive mothers. J Infect $1986 ; 13$ (suppl A): $15-8$

59 Zhu QR, Gu XH, Duan SC, Xu HF. Long-term immunogenicity and efficacy of recombinant yeast derived hepatitis B vaccine for interruption of mother-infant transmission of hepatitis B virus. Chin Med J (Engl) 1994;107:915-8.

$60 \mathrm{Zhu}$ QY. A randomized controlled trial of hepatitis B vaccine in high risk newborn infants in China. [Abstract.]. Aust N Z J Med 1987;17:498

61 Schulz KF, Chalmers I, Hayes RJ, Altman DG. Empirical evidence of bias. Dimensions of methodological quality associated with estimates of treatment effects in controlled trials. JAMA 1995;273:408-12.

62 Kjaergard LL, Villumsen J, Gluud C. Reported methodologic quality and discrepancies between large and small randomized trials in meta-analyses. Ann Intern Med 2001:135:982-9.

63 Als-Nielsen B, Gluud LL, Gluud C. Methodological quality and treatment effects in randomised trials-a review of six empirical studies. [Abstract.] Proceedings of the 12th Cochrane Colloquium.O-072. Ottawa, Canada, 2004

64 Heijtink RA, Kruining J, van Bergen P, de Rave S, van Hattum J, Schutten M, et al. Characterization of a human monoclonal antibody obtained after immunization with plasma vaccine and a booster with recombinant-DNA hepatitis B vaccine. J Med Virol 2002;66:304-11.

65 MacGregor I. Screening assays for transmissible spongiform encephalopathies (TSEs). Vox Sang 2004;87(suppl 2):3-6.

66 Centers for Disease Control and Prevention. Recommendations to prevent hepatitis B virus transmission-United States, updated. Morb Mortal Wkly Rep 1999;48:33-4.

67 David MS, Norman TB. Immunisation against infectious disease. London: HMSO, 1996

68 Yang Y, Liu C, Chen T, Lee M, Chen S, Shi H, et al. Role of hepatitis B immunoglobulin in infants born to hepatitis B e antigen-negative carrier mothers in Taiwan. Pediatr Infect Dis J 2003;22:584-8.

69 Centers for Disease Control and Prevention. Hepatitis B virus: a comprehensive strategy for eliminating transmission in the United States through universal childhood vaccination: recommendations of the Immunization Practices Advisory Committee (ACIP). Morb Mortal Wkly Rep 1991;40:1-19.

70 Chen W, Gluud C. Vaccines for preventing hepatitis B in health-care workers. Cochrane Database Syst Rev 2005;(4):CD000100.

71 Schroth RJ, Hitchon CA, Uhanova J, Noreddin A, Taback SP, Moffatt MEK, et al. Hepatitis B vaccination for patients with chronic renal failure. Cochrane Database Syst Rev 2004.(3):CD003775.

72 Niu MT, Davis DM, Ellenberg S. Recombinant hepatitis B vaccination of neonates and infants: emerging safety data from the vaccine adverse event reporting system. Pediatr Infect Dis J 1996;15:771-6.

73 Niu MT, Salive ME, Ellenberg SS. Neonatal deaths after hepatitis B vaccine: the vaccine adverse event reporting system, 1991-1998. Arch Pediatr Adolesc Med 1999;153:1279-82.

74 DuVernoy T, Braun M. Hypotonic-hyporesponsive episodes reported to the vaccine adverse event reporting system (VAERS), 1996-1998. Pediatrics 2000;106:E52.

75 Kojouharova M, Teoharov P, Bahtchevanova T, Maeva I, Eginlian A, Deneva M. Safety and immunogenicity of a yeast-derived recombinant hepatitis B vaccine in Bulgarian newborns. Infection 2001;29:342-4.

76 Lewis E, Shinefield HR, Woodruff BA, Black SB, Destefano F, Chen RT, et al. Safety of neonatal hepatitis B vaccine administration. Pediatr Infect Dis J 2001;20:1049-54.

77 Bohlke K, Davis RL, Marcy SM, Braun MM, DeStefano F, Black SB, et al. Risk of anaphylaxis after vaccination of children and adolescents. Pediatrics 2003;112:815-20.

78 Deeks JJ, Dinnes J, D'Amico R, Sowden AJ, Sakarovitch C, Song F, et al. Evaluating nonrandomised intervention studies. Health Technol Assess 2003;7:1-173.

79 International conference on harmonisation expert working group. International conference on harmonisation of technical requirements for registration of pharmaceuticals for human use. ICH harmonised tripartite guideline. Guideline for good clinical practice. In: 1997 CFR and ICH Guidelines. Media, PA: Barnett International/ PAREXEL, 1997.

80 Fisher MA, Eklund SA, James SA, Lin X. Adverse events associated with hepatitis B vaccine in US children less than six years of age, 1993 and 1994. Ann Epidemiol 2001;11:13-21.

81 Hayashi K, Walker AM. Japanese and American reports of randomized trials: differences in the reporting of adverse effects. Control Clin Trials 1996;17:99-110.

82 Ioannidis JP, Lau J. Completeness of safety reporting in randomized trials: an evaluation of 7 medical areas. JAMA 2001;285:437-43.

83 Etminan M, Carleton B, Rochon PA. Quantifying adverse drug events: are systematic reviews the answer? Drug Saf 2004;27:757-61.

84 Funk ML, Rosenberg DM, Lok AS. World-wide epidemiology of HBeAg-negative chronic hepatitis B and associated precore and core promoter variants. J Viral Hepat 2002;9:52-61.

85 Bloom BS, Hillman AL, Fendrick AM, Schwartz JS. A reappraisal of hepatitis B virus vaccination strategies using cost-effectiveness analysis. Ann Intern Med 1993;118:298306. 


\section{Research}

86 Da Villa G, Sepe A. Immunization programme against hepatitis B virus infection in Italy: cost-effectiveness. Vaccine 1999;17:1734-8.

87 Tormans G, Van Damme P, Carrin G, Clara R, Eylenbosch W. Cost-effectiveness analysis of prenatal screening and vaccination against hepatitis B virus-the case of Belgium Soc Sci Med 1993;37:173-81

88 Harris A, Yong K, Kermode M. An economic evaluation of universal infant vaccination against hepatitis $\mathrm{B}$ virus using a combination vaccine (Hib-HepB): a decision analytic approach to cost effectiveness. Aust N Z J Public Health 2001;25:222-9.

89 Maroolis $\mathrm{H}$, Coleman P, Brown R, Mast E, Sheingold S, Arevalo J Prevention of hepatitis $\mathrm{B}$ virus transmission by immunization. An economic analysis of current recommendations. JAMA 1995;274:1201-8.

90 Hall AJ, Robertson RL Crivelli PE Lowe Y, Inskip H, Snow SK, et al. Cost-effectiveness of hepatitis B vaccine in the Gambia. Trans R Soc Trop Med Hyg 1993;87:333-6.

91 Liu ZG, Zhao SL, Zhang YX. [Cost-benefit analysis on immunization of newborns with hepatitis B vaccine in Jinan City]. Zhonghua Liu Xing Bing Xue Za Zhi 1995;16:81-4.

92 Sriprakash I, Anil T. Routine prenatal screening of Indian women for HBsAg: benefit derived versus cost. Trop Doct 1997;27:176-7.

93 Zhu Q, Lu Q, Gu X, Xu H, Duan S. A preliminary study on interruption of HBV transmission in uterus. Chin Med J (Engl) 1997;110:145-7.

$94 \mathrm{Li}$ XM, Yang YB, Hou HY, Shi ZJ, Shen HM, Teng BQ, et al. Interruption of HBV intrauterine transmission: a clinical study. World J Gastroenterol 2003;9:1501-3.
(Accepted 14 November 2005)

doi 10.1136/bmj.38719.435833.7C

Cochrane Hepato-Biliary Group, Copenhagen Trial Unit, Copenhagen University Hospital; Department of Pharmacy Practice, Tri-Service General Hospital, Taipei, Taiwan

Chuanfang Lee clinical pharmacist

Cochrane Hepato-Biliary Group, Copenhagen Trial Unit, Centre for Clinical Intervention Research, H:S Rigshospitalet, Copenhagen University Hospital,

Blegdamsvej 9, 2100 Copenhagen, Denmark

Yan Gong research assistant

Jesper Brok research assistant

Christian Gluud head of department

Health Protection Agency, Public Health Laboratory, Heart of England NHS Trust, Birmingham

Elizabeth H Boxall consultant clinical scientist

Correspondence to: Y Gong ygong@ctu.rh.dk 